Kristina Jauković Jocić ${ }^{1}$

Darjan Karabašević ${ }^{2}$

Gabrijela Popović ${ }^{3}$

University Business Academy in Novi Sad

Faculty of Applied Management, Economics and Finance
ORIGINAL SCIENTIFIC ARTICLE

DOI: 10.5937/ekonomika2004047J

Received: April, 17. 2020.

Accepted: Jun, 22. 2020.

\title{
AN APPROACH FOR E-LEARNING COURSES EVALUATION BASED ON THE EDAS METHOD
}

\begin{abstract}
The development and increasing use of information and communication technology and the Internet as well, have facilitated access to educational materials and increased the popularity of e-learning courses. The increase in the number of e-learning courses imposes the need for evaluating their quality. As a result, the criteria and procedures for evaluating the quality of e-courses are becoming increasingly important. Therefore, the use of the EDAS method for evaluating the quality of e-courses is discussed in this paper. The four e-courses are assessed against the seven evaluation criteria obtained on the basis of the literature review. The evaluation process is performed in the group decision-making environment with the aim of obtaining more reliable results.
\end{abstract}

Keywords: EDAS, MCDM, group decision-making, e-learning, content, quality

JEL classification: C44, I29, M15

\section{ПРИСТУП ЕВАЛУАЦИЈИ КУРСЕВА ДАЉИНСКОГ УЧЕЊА ЗАСНОВАН НА ЕДАС МЕТОДИ}

\begin{abstract}
Апатракт
Развој и расй иримене информационо-комуникационих

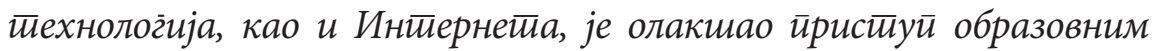

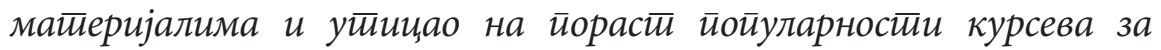
давинско учеюе. Порасти броја наведених курсева довео је и до

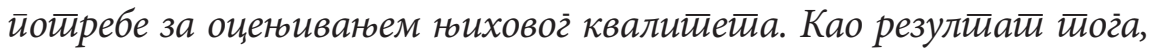
крииееријуми и ирроцедуре за евалуацију елекитронских курсева су иосииали изузейно важни. Из йог разлога, у овом раду је ириказана иримена ЕДАС метиоде за евалуацију квалииетйа елекитронских курсева. Извриена је очена чеиичри елекитронска курса заснована

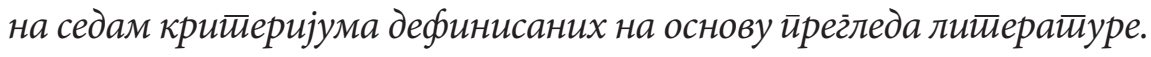

\footnotetext{
${ }^{1}$ kristina.jaukovic@mef.edu.rs, ORCID ID 0000-0002-7113-6269

2 darjan.karabasevic@mef.edu.rs, ORCID ID 0000-0001-5308-2503

${ }^{3}$ gabrijela.popovic@mef.edu.rs, ORCID ID 0000-0002-2652-4860
} 
Процес евалуације је изведен у условима груйног̃ одлучивағьа у изилу добијана иимо релеваниинијих резулииатиа.

Кльчне речи: ЕДАС, ВКО, гіруйно одлучиване, елекиронско учеґе, садржај, квалитеиеи

\section{Introduction}

The development of the Internet has seriously changed the industrial and business activity in the world. Additionally, Internet caused the revolution in education by introducing the learning based on the Internet technology. The use of this technology accelerates exchanging of information and facilitates the education management and performing the given tasks (Tzeng et al., 2007). In that way, the learning process is not connected to the particular place or period of time. Now, a student could choose when and where he/she will perform the studying.

Designing an e-learning course is not easy task for a faculty or other type of educational institution. The e-learning course could not be developed independently from the environment. In other words, the student needs and expectations should be considered before and during the realization of the online course. So, the technical functionality of the online course is as much important as its capacity for adaptation to the changes of the environment (Graf \& List, 2005).

Assessment of the usability and quality of the online course is not an easy task. Besides, identifying the users of the online course as well as the tasks in an online context are the aditional obstacle (Zaharias \& Poylymenakou, 2009). The convenient tool for the assessment of the online courses could be the Multiple Criteria Decision Making (MCDM) methods. The MCDM can be described as the process of selecting the most appropriate from a set of available alternatives. However, MCDM can be defined as a process of ranking and prioritizing alternatives.

In addition to many known MCDM methods, such as: SAW (MacCrimmon, 1968), AHP (Saaty, 1980), TOPSIS (Hwang and Yoon, 1981), PROMETHEE (Brans and Vickine, 1985), ELECTRE (Roy, 1991), VIKOR (Opricovic, 1998), some new MCDM methods have been proposed, such as: COPRAS (Zavadskas et al., 1994), ARAS (Zavadskas and Turskis, 2010), EADS (Keshavarz Ghorabaee et al., 2015). Until now, the MCDM methods have been used for the facilitation of decision-making process in many business fields such as: hotel and tourism industry (Stanujkic et al., 2017a; Karabašević et al., 2019; Popovic et al., 2019a; Popovic et al., 2019b), IT industry (Karabasevic et al., 2018), negotiation (Stanujkic et al., 2017b), household issues (Hassanpour \& Pamucar, 2019), transport (Çam \& Sezen, 2020), etc.

The evaluation of the e-learning websites occupied significant research attention which proves a number of papers that elaborate the mentioned topic, only to mention some of them, Garg and Jain (2017) proposed the application of the FAHP, COPRAS, VIKOR and WDBA methods in the case of the e-learning website selection, while Khan et al. (2019) applied the PIV method for the same purpose. The analysis of the components of e-learning systems and its prioritization is, also, performed by using the MCDM methods (Çelikbilek \&Adıgüzel Tüylü, 2019). 
For the purpose of this paper, the application of the EDAS method is proposed. The reason for the proposing mentioned method reflects thorough the fact that it is simple, understandable, and convenient for facilitation the business problems. Therefore, the remaining part of the paper is organized as follows: In the second section, the EDAS method is presented and in the third section a numerical illustration is considered. Finally, the conclusions are given.

\section{The EDAS method}

As previously mentioned, the EDAS has been introduced by Keshavarz Ghorabaee et al. (2015). Similar to the very popular TOPSIS method, the EDAS method uses two distance measures to select the most appropriate alternative, but the calculation procedures are quite different. The EDAS method use two distance measures, namely the Positive Distance from Average (PDA) and the Negative Distance from Average (NDA), and that the most appropriate alternative is the alternative that has higher value of PDA and lower value of NDA.

The computational procedure of the EDAS method, for decision-making problem with $m$ criteria and $n$ alternatives, can be precisely presented as follows (Stanujkic et al., 2017c):

Step 1. Select the available alternatives, the most important criteria that describe alternatives, and rank alternatives in order to selected criteria. As a result, a decision matrix has been formed.

Step 2. Determine the average solution according to all criteria, shown as follows:

$$
x_{j}=\left(x_{1}, x_{2}, \cdots, x_{n}\right) \text {, }
$$

with:

$$
\mathfrak{x}_{j}=\frac{\sum_{i=1}^{m} x_{\boldsymbol{j}}}{m} .
$$

where $x_{i j}$ denotes the rating of the alternative $i$ in the relation of the criterion $j$.

Step 3. Calculate the positive distance from average $d_{i j}^{-}$and the negative distance from average $d_{i j}^{-}$according to the type of criteria (beneficial and non-beneficial) as follows:

$$
\begin{aligned}
& d_{j}^{+}=\left\{\begin{array}{ll}
\frac{\max \left(0,\left(x_{j}-x_{j}\right)\right.}{x_{j}} ; & j \in \Omega_{\max } \\
\frac{\max \left(0,\left(x_{j}-x_{j}\right)\right.}{x_{j}} ; & j \in \Omega_{\min }
\end{array},\right. \\
& d_{j}^{-}= \begin{cases}\frac{\max \left(0,\left(x_{j}-x_{j}\right)\right.}{x_{j}} ; & j \in \Omega_{\max } \\
\frac{\max \left(0,\left(x_{j}-x_{j}\right)\right.}{x_{j}} ; & j \in \Omega_{\min },\end{cases}
\end{aligned}
$$


where: $\Omega_{\max }$ and $\Omega_{\min }$ denotes the set of beneficial and non-beneficial criteria, respectively.

For a decision-making problem involving only the beneficial criteria $d_{i j}^{+} d_{\ddot{j}}^{-}$can be determined as follows:

$$
\begin{aligned}
& d_{i j}^{+}=\frac{\max \left(0,\left(x_{j}-x_{j}\right)\right.}{x_{j}}, \\
& d_{i j}^{-}=\frac{\max \left(0,\left(x_{j}-x_{j}\right)\right.}{x_{j}} .
\end{aligned}
$$

Step 4. Determine the weighted sum of PDA, $Q_{i}^{+}$, and weighted sum of NDS, $Q_{i}^{-}$, for all alternatives, as follows:

$$
\begin{aligned}
& Q_{i}^{+}=\sum_{j=1}^{n} w_{j} d_{j}^{+}, \\
& Q_{i}^{-}=\sum_{j=1}^{n} w_{j} d_{j}^{-} .
\end{aligned}
$$

Step 5. Normalize the values of weighted sum of PDA and weighted sum of NDA for all alternatives, as follows:

$$
\begin{aligned}
& S_{i}^{+}=\frac{Q_{i}^{+}}{\max _{i} S_{i}^{+}}, \\
& S_{i}^{-}=1-\frac{Q_{i}^{-}}{\max _{i} S_{i}^{-}},
\end{aligned}
$$

where $S_{i}^{+}$and $S_{i}^{-}$denote the normalized weighted sum of PDA and NDA, respectively.

Step 6. Calculate the appraisal score $S_{i}$ for all alternatives, as follows:

$$
S_{i}=\frac{1}{2}\left(S_{i}^{+}+S_{i}^{-}\right)
$$

Step 7. Rank the alternatives according to the decreasing values of the appraisal score. The alternative with the highest $S_{i}$ is the best choice among the candidate alternatives.

\section{The use of EDAS method for group decision-making}

Solving complex decision-making problems require the involvement of a number of respondents. In such cases, personal attitudes have to be transformed into the 
group attitudes. For a team consisting of $K$ respondents the individual attitudes can be transformed into a group as follows:

$$
x_{i j}=\frac{1}{K} \sum_{k=1}^{K} x_{j}^{k} \text {, }
$$

where $x_{i j}^{k}$ denotes attitude of alternative $i$ in relation to criterion $j$ obtained from decision-maker $k$, and $x_{i j}$ denotes the rating of the alternative $i$ in the relation of the criterion $j$.

\section{A Numerical Illustration}

In this case study, four e-learning courses, designated as $A_{1}, A_{2}, A_{3}$, and $A_{4}$, have been evaluated on the basis of seven criteria by twenty-four respondents. The criteria used for the evaluation, as well as their weights, are shown in Table 1.

The responses, computational details, and weight obtained from the first of three randomly selected respondents are shown in Tables 1,2 , and 3.

Table 1: The criteria and weights of criteria

\begin{tabular}{llc}
\hline Criteria & & $w_{j}$ \\
\hline$C_{1}$ & Level of content & 0.14 \\
$C_{2}$ & Presentation method & 0.14 \\
$C_{3}$ & Teaching method & 0.13 \\
$C_{4}$ & e-learning environment & 0.14 \\
$C_{5}$ & Learning materials & 0.15 \\
$C_{6}$ & Quality of multimedia content & 0.14 \\
$C_{7}$ & Group work and interactivity & 0.15 \\
\hline
\end{tabular}

The ratings obtained from three to twenty-four respondents are shown in Tables 2 to 4 and on Figures 1 to 3.

Table 2: The ratings obtained from the fist of twenty-four respondents

\begin{tabular}{lccccccc}
\hline Criteria & $C_{1}$ & $C_{2}$ & $C_{3}$ & $C_{4}$ & $C_{5}$ & $C_{6}$ & $C_{7}$ \\
\hline$C_{1}$ & 4 & 3 & 3 & 4 & 2 & 4 & 5 \\
$C_{2}$ & 3 & 5 & 2 & 4 & 4 & 4 & 4 \\
$C_{3}$ & 5 & 5 & 4 & 5 & 3 & 3 & 2 \\
$C_{4}$ & 4 & 5 & 5 & 4 & 4 & 4 & 4 \\
\hline
\end{tabular}


Figure 1: The ratings obtained from the fist of twenty-four respondents

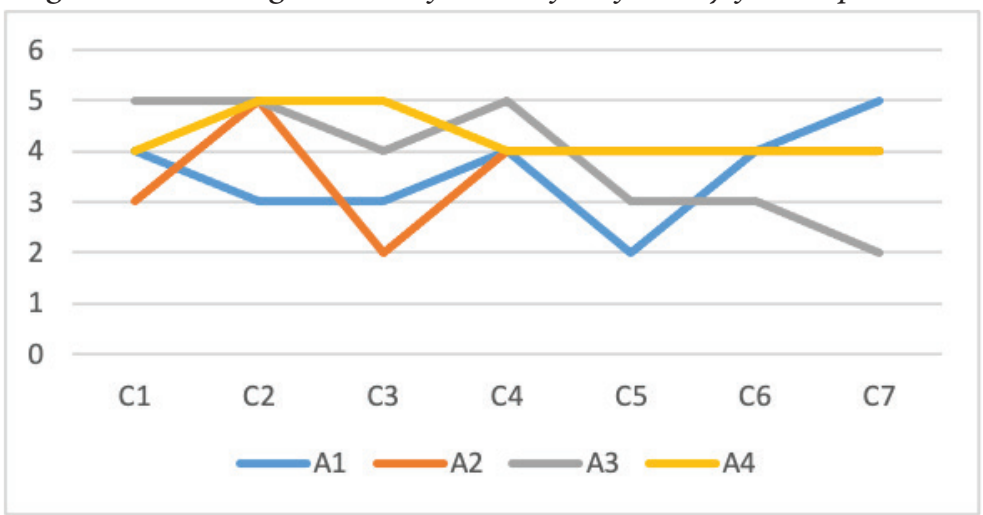

Table 3: The ratings obtained from the second of twenty-four respondents

\begin{tabular}{lccccccc}
\hline Criteria & $C_{1}$ & $C_{2}$ & $C_{3}$ & $C_{4}$ & $C_{5}$ & $C_{6}$ & $C_{7}$ \\
\hline$C_{1}$ & 2 & 3 & 5 & 5 & 2 & 3 & 2 \\
$C_{2}$ & 4 & 5 & 4 & 5 & 4 & 4 & 5 \\
$C_{3}$ & 5 & 4 & 4 & 5 & 5 & 5 & 3 \\
$C_{4}$ & 3 & 5 & 3 & 4 & 4 & 5 & 4 \\
\hline
\end{tabular}

Figure 2: The ratings obtained from the second of twenty-four respondents

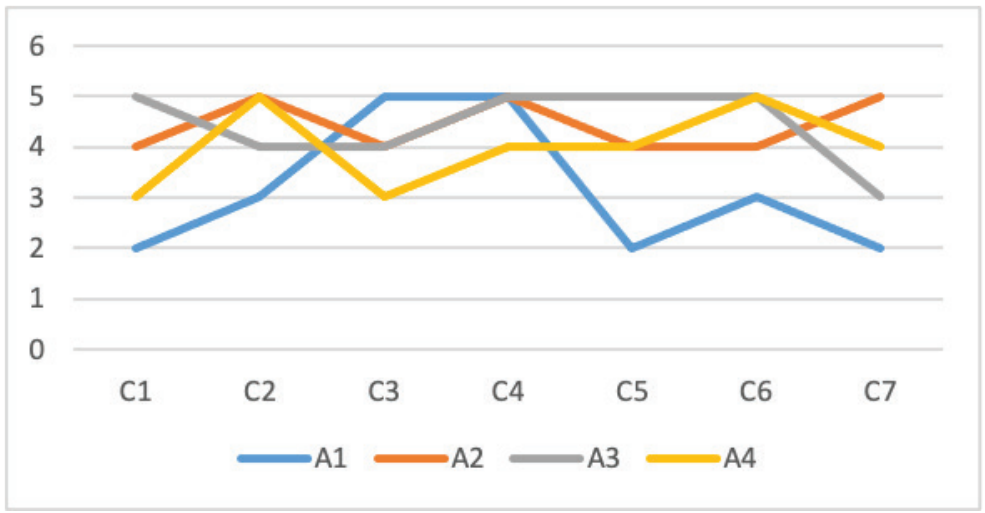

Table 4: The ratings obtained from the third of twenty-four respondents

\begin{tabular}{lccccccc}
\hline Criteria & $C_{1}$ & $C_{2}$ & $C_{3}$ & $C_{4}$ & $C_{5}$ & $C_{6}$ & $C_{7}$ \\
\hline$C_{1}$ & 3 & 3 & 3 & 4 & 5 & 4 & 4 \\
$C_{2}$ & 2 & 4 & 4 & 3 & 2 & 5 & 5 \\
$C_{3}$ & 5 & 4 & 4 & 3 & 4 & 5 & 3 \\
$C_{4}$ & 5 & 5 & 5 & 3 & 3 & 4 & 4 \\
\hline
\end{tabular}


Figure 3: The ratings obtained from the third of twenty-four respondents

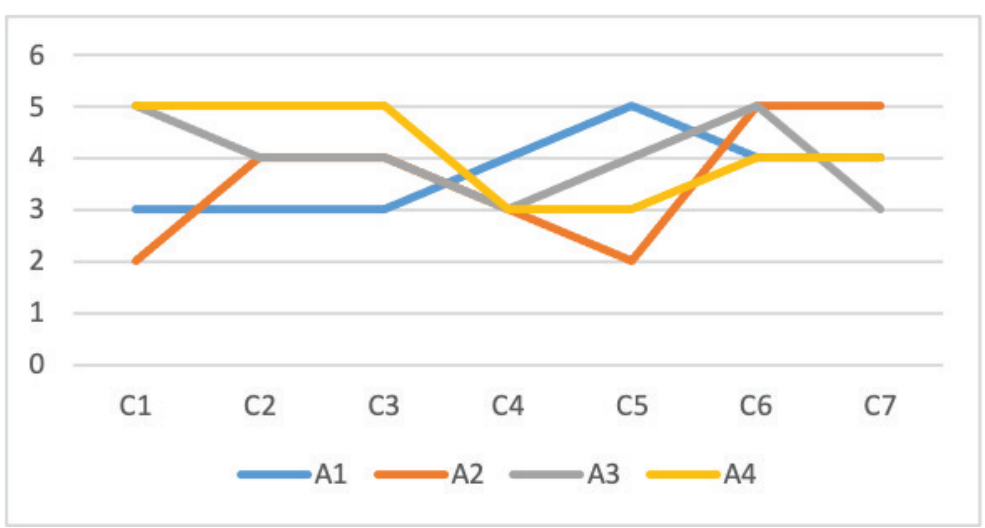

The ratings of the alternative $A_{1}$ obtained from all respondents are shown in Table 5. At the end of this table, the group ratings are also shown.

Table 5: The ratings and group ratings of alternative $A_{1}$

\begin{tabular}{lccccccc}
\hline & $C_{1}$ & $C_{2}$ & $C_{3}$ & $C_{4}$ & $C_{5}$ & $C_{6}$ & $C_{7}$ \\
\hline$R_{1}$ & 4 & 3 & 3 & 4 & 2 & 4 & 5 \\
$R_{2}$ & 2 & 3 & 5 & 5 & 2 & 3 & 2 \\
$R_{3}$ & 3 & 3 & 3 & 4 & 5 & 4 & 4 \\
$R_{4}$ & 4 & 3 & 3 & 4 & 2 & 4 & 5 \\
$R_{5}$ & 3 & 4 & 5 & 4 & 3 & 2 & 2 \\
$R_{6}$ & 4 & 4 & 2 & 4 & 5 & 4 & 4 \\
$R_{7}$ & 3 & 5 & 4 & 4 & 4 & 5 & 5 \\
$R_{9}$ & 4 & 4 & 4 & 5 & 4 & 5 & 4 \\
$R_{10}$ & 3 & 3 & 5 & 3 & 3 & 1 & 2 \\
$R_{11}$ & 4 & 5 & 4 & 5 & 5 & 4 & 3 \\
$R_{12}$ & 3 & 5 & 4 & 4 & 4 & 4 & 4 \\
$R_{13}$ & 2 & 2 & 3 & 2 & 1 & 2 & 3 \\
$R_{14}$ & 3 & 4 & 3 & 2 & 4 & 2 & 4 \\
$R_{15}$ & 4 & 2 & 2 & 3 & 4 & 5 & 3 \\
$R_{16}$ & 3 & 4 & 5 & 4 & 3 & 2 & 2 \\
$R_{17}$ & 2 & 3 & 3 & 2 & 3 & 2 & 3 \\
$R_{18}$ & 2 & 2 & 2 & 1 & 2 & 2 & 1 \\
$R_{19}$ & 5 & 4 & 4 & 5 & 4 & 3 & 2 \\
$R_{20}$ & 1 & 3 & 3 & 1 & 2 & 1 & 2 \\
$R_{21}$ & 4 & 3 & 3 & 4 & 2 & 4 & 5 \\
$R_{22}$ & 2 & 2 & 3 & 3 & 2 & 2 & 2 \\
$R_{23}$ & 3 & 5 & 4 & 2 & 3 & 4 & 2 \\
$R_{24}$ & 5 & 4 & 5 & 4 & 3 & 2 & 3 \\
\hline Avg. & 3.25 & 3.50 & 3.63 & 3.46 & 3.13 & 3.04 & 3.13 \\
\hline & & & & & & &
\end{tabular}


The ratings obtained for alternatives $A_{2}, A_{3}$, and $A_{4}$ are similarly presented in Tables 6,7 , and 8 .

Table 6: The ratings and group ratings of alternative $A_{2}$

\begin{tabular}{lccccccc}
\hline & $C_{1}$ & $C_{2}$ & $C_{3}$ & $C_{4}$ & $C_{5}$ & $C_{6}$ & $C_{7}$ \\
\hline$R_{1}$ & 3 & 5 & 2 & 4 & 4 & 4 & 4 \\
$R_{2}$ & 4 & 5 & 4 & 5 & 4 & 4 & 5 \\
$R_{3}$ & 2 & 4 & 4 & 3 & 2 & 5 & 5 \\
$R_{4}$ & 4 & 3 & 4 & 4 & 4 & 4 & 4 \\
$R_{5}$ & 3 & 3 & 4 & 4 & 4 & 4 & 4 \\
$R_{6}$ & 5 & 3 & 5 & 4 & 4 & 4 & 4 \\
$R_{7}$ & 5 & 3 & 5 & 4 & 4 & 4 & 4 \\
$R_{9}$ & 2 & 5 & 4 & 4 & 4 & 5 & 4 \\
$R_{10}$ & 3 & 5 & 5 & 5 & 4 & 5 & 5 \\
$R_{11}$ & 3 & 5 & 2 & 4 & 4 & 4 & 4 \\
$R_{12}$ & 3 & 4 & 4 & 4 & 5 & 5 & 2 \\
$R_{13}$ & 2 & 3 & 2 & 2 & 1 & 4 & 2 \\
$R_{14}$ & 3 & 2 & 2 & 2 & 3 & 2 & 3 \\
$R_{15}$ & 3 & 3 & 3 & 3 & 4 & 4 & 3 \\
$R_{16}$ & 3 & 3 & 4 & 4 & 4 & 4 & 4 \\
$R_{17}$ & 2 & 3 & 3 & 3 & 3 & 2 & 3 \\
$R_{18}$ & 3 & 3 & 2 & 2 & 3 & 2 & 1 \\
$R_{19}$ & 5 & 4 & 3 & 5 & 4 & 4 & 5 \\
$R_{20}$ & 3 & 5 & 2 & 4 & 4 & 4 & 4 \\
$R_{21}$ & 4 & 5 & 4 & 4 & 3 & 4 & 2 \\
$R_{22}$ & 3 & 3 & 4 & 3 & 2 & 2 & 3 \\
$R_{23}$ & 2 & 3 & 3 & 2 & 4 & 3 & 4 \\
$R_{24}$ & 4 & 3 & 4 & 2 & 2 & 2 & 4 \\
\hline$A v g$. & 3.29 & 3.71 & 3.50 & 3.54 & 3.46 & 3.71 & 3.58 \\
\hline & & & & & & &
\end{tabular}

Table 7: The ratings and group ratings of alternative $A_{3}$

\begin{tabular}{lccccccc}
\hline & $C_{1}$ & $C_{2}$ & $C_{3}$ & $C_{4}$ & $C_{5}$ & $C_{6}$ & $C_{7}$ \\
\hline$R_{1}$ & 5 & 5 & 4 & 5 & 3 & 3 & 2 \\
$R_{2}$ & 5 & 4 & 4 & 5 & 5 & 5 & 3 \\
$R_{3}$ & 5 & 4 & 4 & 3 & 4 & 5 & 3 \\
$R_{4}$ & 5 & 3 & 4 & 5 & 4 & 4 & 5 \\
$R_{5}$ & 3 & 5 & 3 & 3 & 4 & 5 & 2 \\
$R_{6}$ & 5 & 3 & 3 & 5 & 3 & 3 & 3 \\
$R_{7}$ & 3 & 4 & 3 & 3 & 3 & 4 & 4 \\
$R_{9}$ & 3 & 5 & 5 & 5 & 5 & 3 & 5 \\
$R_{10}$ & 4 & 3 & 2 & 5 & 3 & 4 & 3 \\
$R_{11}$ & 3 & 4 & 5 & 3 & 3 & 5 & 4 \\
$R_{12}$ & 3 & 3 & 4 & 4 & 5 & 4 & 5 \\
$R_{13}$ & 3 & 2 & 1 & 1 & 3 & 5 & 3
\end{tabular}




\begin{tabular}{lccccccc}
$R_{14}$ & 5 & 4 & 4 & 3 & 4 & 5 & 3 \\
$R_{15}$ & 5 & 3 & 4 & 5 & 4 & 4 & 5 \\
$R_{16}$ & 3 & 5 & 3 & 3 & 4 & 5 & 2 \\
$R_{17}$ & 5 & 3 & 3 & 5 & 3 & 3 & 3 \\
$R_{18}$ & 3 & 1 & 1 & 2 & 4 & 1 & 2 \\
$R_{19}$ & 4 & 5 & 2 & 5 & 4 & 4 & 4 \\
$R_{20}$ & 1 & 3 & 1 & 1 & 3 & 1 & 3 \\
$R_{21}$ & 5 & 5 & 4 & 5 & 3 & 3 & 2 \\
$R_{22}$ & 5 & 5 & 4 & 5 & 3 & 3 & 2 \\
$R_{23}$ & 3 & 3 & 2 & 1 & 3 & 1 & 2 \\
$R_{24}$ & 4 & 2 & 3 & 4 & 1 & 3 & 3 \\
\hline$A v g$. & 3.92 & 3.71 & 3.17 & 3.79 & 3.54 & 3.63 & 3.13 \\
\hline
\end{tabular}

Table 8: The ratings and group ratings of alternative $A_{4}$

\begin{tabular}{lccccccc}
\hline & $C_{1}$ & $C_{2}$ & $C_{3}$ & $C_{4}$ & $C_{5}$ & $C_{6}$ & $C_{7}$ \\
\hline$R_{1}$ & 4 & 5 & 5 & 4 & 4 & 4 & 4 \\
$R_{2}$ & 3 & 5 & 3 & 4 & 4 & 5 & 4 \\
$R_{3}$ & 5 & 5 & 5 & 3 & 3 & 4 & 4 \\
$R_{4}$ & 4 & 5 & 3 & 4 & 4 & 4 & 4 \\
$R_{5}$ & 4 & 4 & 3 & 4 & 3 & 4 & 4 \\
$R_{6}$ & 4 & 5 & 2 & 4 & 4 & 4 & 4 \\
$R_{7}$ & 3 & 5 & 5 & 3 & 3 & 5 & 4 \\
$R_{9}$ & 2 & 5 & 4 & 4 & 5 & 4 & 5 \\
$R_{10}$ & 4 & 5 & 5 & 4 & 5 & 4 & 3 \\
$R_{11}$ & 4 & 4 & 5 & 5 & 5 & 3 & 3 \\
$R_{12}$ & 5 & 4 & 3 & 2 & 4 & 5 & 4 \\
$R_{13}$ & 2 & 2 & 4 & 1 & 4 & 2 & 2 \\
$R_{14}$ & 3 & 4 & 2 & 4 & 3 & 2 & 2 \\
$R_{15}$ & 3 & 5 & 4 & 4 & 5 & 2 & 3 \\
$R_{16}$ & 3 & 4 & 4 & 3 & 5 & 2 & 5 \\
$R_{17}$ & 2 & 2 & 3 & 2 & 3 & 2 & 3 \\
$R_{18}$ & 2 & 2 & 2 & 1 & 1 & 1 & 2 \\
$R_{19}$ & 5 & 4 & 5 & 4 & 4 & 3 & 3 \\
$R_{20}$ & 4 & 5 & 5 & 4 & 4 & 4 & 4 \\
$R_{21}$ & 4 & 5 & 3 & 5 & 5 & 2 & 2 \\
$R_{22}$ & 3 & 3 & 2 & 2 & 1 & 2 & 2 \\
$R_{23}$ & 2 & 2 & 3 & 4 & 4 & 2 & 2 \\
$R_{24}$ & 3 & 1 & 2 & 3 & 5 & 2 & 5 \\
\hline Avg. & 3.46 & 4.00 & 3.63 & 3.38 & 3.79 & 3.13 & 3.38 \\
\hline & & & & & & &
\end{tabular}

Finally, the group rating of alternatives are shown in Table 9. 
Table 9: The group ratings of considered alternatives, and the average solution

\begin{tabular}{lccccccc}
\hline & $C_{1}$ & $C_{2}$ & $C_{3}$ & $C_{4}$ & $C_{5}$ & $C_{6}$ & $C_{7}$ \\
\hline$A_{1}$ & 3.25 & 3.50 & 3.63 & 3.46 & 3.13 & 3.04 & 3.13 \\
$A_{2}$ & 3.29 & 3.71 & 3.50 & 3.54 & 3.46 & 3.71 & 3.58 \\
$A_{3}$ & 3.92 & 3.71 & 3.17 & 3.79 & 3.54 & 3.63 & 3.13 \\
$A_{4}$ & 3.46 & 4.00 & 3.63 & 3.38 & 3.79 & 3.13 & 3.38 \\
\hline$x_{j}$ & 3.48 & 3.73 & 3.48 & 3.54 & 3.48 & 3.38 & 3.30 \\
\hline
\end{tabular}

The average solution, according to all criteria, obtained using Eqs. (1) and (2), is also shown in the last row on Table 9.

The positive distances from average, calculated using Eq. (5), and the negative distances from average, calculated using Eq. (6), are shown in Table 10 and Table 11, respectively.

Table 10: The positive distances from average

\begin{tabular}{cccccccc}
\hline & $C_{1}$ & $C_{2}$ & $C_{3}$ & $C_{4}$ & $C_{5}$ & $C_{6}$ & $C_{7}$ \\
\hline$A_{1}$ & 0.000 & 0.000 & 0.042 & 0.000 & 0.000 & 0.000 & 0.000 \\
$A_{2}$ & 0.000 & 0.000 & 0.006 & 0.000 & 0.000 & 0.099 & 0.085 \\
$A_{3}$ & 0.126 & 0.000 & 0.000 & 0.071 & 0.018 & 0.074 & 0.000 \\
$A_{4}$ & 0.000 & 0.073 & 0.042 & 0.000 & 0.090 & 0.000 & 0.022 \\
\hline
\end{tabular}

Table 11: The negative distances from average

\begin{tabular}{cccccccc}
\hline & $C_{1}$ & $C_{2}$ & $C_{3}$ & $C_{4}$ & $C_{5}$ & $C_{6}$ & $C_{7}$ \\
\hline$A_{1}$ & 0.066 & 0.061 & 0.000 & 0.024 & 0.102 & 0.099 & 0.054 \\
$A_{2}$ & 0.054 & 0.006 & 0.000 & 0.000 & 0.006 & 0.000 & 0.000 \\
$A_{3}$ & 0.000 & 0.006 & 0.090 & 0.000 & 0.000 & 0.000 & 0.054 \\
$A_{4}$ & 0.006 & 0.000 & 0.000 & 0.047 & 0.000 & 0.074 & 0.000 \\
\hline
\end{tabular}

Weighted sum of PDA and NDA, obtained using Eq. (7) and Eq. (8), and normalized weighted sum of PDA and NDA, obtained using Eq. (9) and Eq. (10), are shown in Table 12.

Table 12: Calculation details obtained using EDAS method

\begin{tabular}{lcccccc}
\hline & $Q_{i}^{-}$ & $Q_{i}^{-}$ & $S_{i}^{-}$ & $S_{i}^{-}$ & $S_{i}$ & Rank \\
\hline$A_{1}$ & 0.01 & 0.06 & 0.14 & 0.00 & 0.07 & 4 \\
$A_{2}$ & 0.03 & 0.01 & 0.66 & 0.84 & 0.75 & 2 \\
$A_{3}$ & 0.04 & 0.02 & 1.00 & 0.65 & 0.82 & 1 \\
$A_{4}$ & 0.03 & 0.02 & 0.78 & 0.69 & 0.74 & 3 \\
\cline { 1 - 3 }$\Sigma$ & 0.04 & 0.06 & & & &
\end{tabular}

The appraisal score $S_{i}$ for each alternative, determined using Eq. (11) is also given in Table 12. On the basis of the appraisal score the alternative denotes as $A_{3}$ is selected as the most appropriate one. 


\section{Conclusion}

Many faculties and institutions design and offer various online courses pointed to different topics. Every one of these institutions has certain advantages and disadvantages in conducting such type of education. The main goal is, certainly, obtaining the quality education and achievement of the desired goal without sacrificing the education standards.

In order to define the advantages and disadvantages of a certain online course, the MCDM techniques could be a very convenient way. The authors proposed different models for the assessment of the quality of the e-learning as well as for the prioritization of the e-learning websites. This paper presents an application of the EDAS method for e-learning courses evaluation. The evaluation was based on the seven criteria that rely on the views of twenty-four respondents.

The main reason for the application of the EDAS method is its simplicity and relevance. The obtained results clearly outlined what features of the online course should be improved, as well as how is it position relative to the competition. The simplicity of the presented method makes it suitable for application by the practitioners outside of the scientific field. By using this method, the practitioners, i. e. the educators that offer e-courses will easily determine what features of its course are good and what should be improved.

The proposed model is based on the application of the crisp numbers, which is the crucial deficiency of this paper. Because of that, the vagueness of the environment i.e. the indecision of the respondents, is not appreciated in the satisfying degree. This shortage could be overcome by using the proper extensions of the proposed method. Afterward, the applicability of the EDAS method certainly could not be denied.

\section{References}

Brans, J. P., Vincke, P. (1985). A preference ranking organization method: The PROMETHEE method for MCDM. Management Science, 31(6), 647-656.

Çam, Ö. N., \& Sezen, H. K. (2020). Linear programming formulation for vehicle routing problem which is minimized idle time. Decision Making: Applications in Management and Engineering, 3(1-2), 22-29.

Çelikbilek, Y., \& Adıgüzel Tüylü, A. N. (2019). Prioritizing the components of e-learning systems by using fuzzy DEMATEL and ANP. Interactive Learning Environments, 1-22.

Garg, R., \& Jain, D. (2017). Fuzzy multi-attribute decision making evaluation of e-learning websites using FAHP, COPRAS, VIKOR, WDBA. Decision Science Letters, 6(4), 351-364.

Ghorabaee, M. K., Amiri, M., Zavadskas, E. K., Turskis, Z., \& Antucheviciene, J. (2017). A new multi-criteria model based on interval type-2 fuzzy sets and EDAS method for supplier evaluation and order allocation with environmental considerations. Computers \& Industrial Engineering, 112, 156-174.

Graf, S., \& List, B. (2005, July). An evaluation of open source e-learning platforms stressing adaptation issues. In Fifth IEEE International Conference on Advanced Learning Technologies (ICALT’05) (pp. 163-165). IEEE. 
Hassanpour, M., \& Pamucar, D. (2019). Evaluation of Iranian household appliance industries using MCDM models. Operational Research in Engineering Sciences: Theory and Applications, 2(3), 1-25.

Hwang, C. L. and Yoon, K. (1981). Multiple Attribute Decision Making: Methods and Applications, Springer-Verlag, New York.

Kahraman, C., Keshavarz Ghorabaee, M., Zavadskas, E. K., Cevik Onar, S., Yazdani, M., \& Oztaysi, B. (2017). Intuitionistic fuzzy EDAS method: an application to solid waste disposal site selection. Journal of Environmental Engineering and Landscape Management, 25(1), 1-12.

Karabasevic, D., Zavadskas, E. K., Stanujkic, D., Popovic, G., \& Brzakovic, M. (2018). An approach to personnel selection in the IT industry based on the EDAS method. Transformations in Business \& Economics, 17(2), 44-65.

Karabašević, D., Popović, G., Stanujkić, D., Maksimović, M., \& Sava, C. (2019). An approach for hotel type selection based on the single-valued intuitionistic fuzzy numbers. International Review, (1-2), 7-14.

Keshavarz Ghorabaee, M., Zavadskas, E. K., Olfat, L., \& Turskis, Z. (2015). Multicriteria inventory cilassification using a new method of Evaluation Based on Distance from Average Solution (EDAS). Informatica, 26(3), 435-451.

Khan, N. Z., Ansari, T. S. A., Siddiquee, A. N., \& Khan, Z. A. (2019). Selection of E-learning websites using a novel Proximity Indexed Value (PIV) MCDM method. Journal of Computers in Education, 6(2), 241-256.

MacCrimmon, K. R. (1968). Decision Marking Among Multiple-Attribute Alternatives: a Survey and Consolidated Approach. RAND memorandum, RM-4823-ARPA.

Opricovic, S. (1998). Multicriteria Optimization of Civil Engineering Systems. Faculty of Civil Engineering, Belgrade. (In Serbian)

Popovic, G., Stanujkic, D., Brzakovic, M., \& Karabasevic, D. (2019a). A multiplecriteria decision-making model for the selection of a hotel location. Land use policy, 84, 49-58.

Popovic, G., Stanujkic, D., \& Karabasevic, D. (2019b). A framework for the evaluation of hotel property development projects. International Journal of Strategic Property Management, 23(2), 96-107.

Roy, B. (1991). The Outranking Approach and the Foundation of ELECTRE Methods. Theory and Decision, 31(1), 49-73.

Saaty, T. L. (1980). Analytic Hierarchy Process: Planning, Priority Setting, Resource Allocation. McGraw-Hill, New York.

Stanujkic, D., Zavadskas, E. K., Karabasevic, D., Urosevic, S., \& Maksimovic, M. (2017a). An approach for evaluating website quality in hotel industry based on triangular intuitionistic fuzzy numbers. Informatica, 28(4), 725-748.

Stanujkic, D., Zavadskas, E. K., Karabasevic, D., Turskis, Z., \& Keršulienè, V. (2017a). New group decision-making ARCAS approach based on the integration of the SWARA and the ARAS methods adapted for negotiations. Journal of Business Economics and Management, 18(4), 599-618. 
Stanujkic, D., Zavadskas, E. K., Ghorabaee, M. K., \& Turskis, Z. (2017b). An extension of the EDAS method based on the use of interval grey numbers. Studies in Informatics and Control, 26(1), 5-12.

Stevic, Z., Vasiljevic, M., Zavadskas, E. K., Sremac, S., \& Turskis, Z. (2018). Selection of carpenter manufacturer using fuzzy EDAS method. Inzinerine EkonomikaEngineering Economics, 29, 281-290.

Tzeng, G. H., Chiang, C. H., \& Li, C. W. (2007). Evaluating intertwined effects in e-learning programs: A novel hybrid MCDM model based on factor analysis and DEMATEL. Expert systems with Applications, 32(4), 1028-1044.

Zavadskas, E. K., Kaklauskas, A., Sarka, V. (1994). The new method of multicriteria complex proportional assessment of projects. Technological and Economic Development of Economy, 1(3), 131-139.

Zavadskas, E. K., Turskis, Z. (2010). A new additive ratio assessment (ARAS) method in multicriteria decision-making. Technological and Economic Development of Economy, 16(2), 159-172.

Zaharias, P., \& Poylymenakou, A. (2009). Developing a usability evaluation method for e-learning applications: Beyond functional usability. Intl. Journal of HumanComputer Interaction, 25(1), 75-98. 
